\title{
The Ways and Means of the Ukrainian Nation's Self-Determination: a Philosophical Look into the Future by Julian Vassyian
}

\author{
Daria Pohribna \\ Ph.D., Associate Professor, Infrastructure and Technology State University \\ (Kyiv, Ukraine) \\ E-mail: dariavladyslavivna@gmail.com \\ https://orcid.org/0000-0001-6333-8576 \\ Vadym Tytarenko \\ Ph.D., Associate Professor, Taras Shevchenko National University of Kyiv \\ (Kyiv, Ukraine) \\ E-mail: tytarenko.vadym@gmail.com \\ https://orcid.org/0000-0001-9251-8859
}

The paper is devoted to further development of the criteria for identifying the Ukrainian nation. It is claimed that the effective strategy for such identification could be found in the theory of nation by the 20th-century Ukrainian philosopher Julian Vassyian. His main theoretical writings are focused on the "inner" factors which considered being crucial in terms of self-determination of the Ukrainian nation. In philosopher's opinion, the foreign policy factors are not as essential for the nation's self-identification as "inner" criteria, which are the national character, volitional activity and spiritual unity. He claimed that the definition of the objective "external" criteria such as language, territory, economic factors, etc. is not essential as well. The main principle of Ukrainian's national self-identification ought to be an awareness of being a representative of the nation and focus voluntary efforts on its development and improvement. Vassyian pays a lot of attention to the analysis of the main treats of the Ukrainian nation. Ukrainians should overcome the historically formed negative traits of the national mindset peacefulness, defensiveness, excessive sentimentalism, social underdevelopment, etc. in order to become active subjects of the historical process. Ukrainian nation's formation mechanism is based on the triad "idea-will-aim." Vassyian's concept of "national genius" acts as a mechanism for activating and directing the individual's will to the formation of the nation.

It is claimed that Vassyian's basic theoretical statements could be productively used by modern nation studies. In the authors'opinion, Vassyian's key ideas could contribute to the solution of current value-formation problems for the modern Ukrainian nation. It is asserted, that particular provisions of Julian Vassian's philosophy of Ukrainian nation could be helpful for the Ukrainian nation development in a modern globalised society.

Keywords: self-determination of the Ukrainian nation; Julian Vassyian, national character; national genius; future political leader image

(C) Pohribna, Daria, 2019

(C) Tytarenko, Vadym, 2019 
The Ways and Means of the Ukrainian Nation's Self-Determination: a Philosophical Look into the Future by Julian Vassyian by Daria Pohribna and Vadym Tytarenko

Received: February 12, 2019; accepted: March 18, 2019

Future Human Image, Volume 11, 2019: 72-82.

https://doi.org/10.29202/fhi/11/8

\section{Introduction}

The self-identification of the Ukrainian nation is one of the most urgent philosophical and political problems of the present. From the middle of the $19^{\text {th }}$ century, Ukrainian thinkers discussed different criteria for identifying the Ukrainian nation as an independent historical unit. In the history of Ukrainian philosophical and political thought, various criteria were mentioned as dominant. The clearest and well known are the followings: a) language in terms of "the idea of nationality" which "...is capable of awakening of public impulses" [Potebnja, 1913: 93]; b) territory: "One, unified, inseparable, free and independent Ukraine from the Carpathians up to the Caucasus" [Mikhnovsky, 2000: 153]; c) "economic interests" which "unite the native speakers of the same language into one political integrity" [Bachinsky, 2000: 145]; d) dynamic political activity as "impactful nationalism" [Dontsov, 2000: 189]; e) the existence of a strong traditional state power, which means that "the renaissance of Ukrainian conservatism is required for complete formation of the Ukrainian nation" [Lypynsky, 1995: 444].

However, the Ukrainian nation in terms of a social organism is not fully formed and identified yet. Such a state is evidenced by political instability and cultural antagonism in particular regions of Ukraine. The globalized society proclaiming "a life without borders and nations" appears to be a direct threat to the existence of nations in the traditional sense of the concept (language, territory, ethnicity, traditions, etc.)

In search of effective criteria for Ukrainian national identification, it is expedient to reconsider the philosophical writings by $20^{\text {th }}$ century Ukrainian philosopher, historian, ideologue, and publicist Julian Vassyian. Having a PhD in philosophy, he was at the same time an active ideologist of the Organization of Ukrainian Nationalists. The written heritage of the philosopher is a good example of a combination of meaningful theoretical positions with practical political activity. Therefore, Vassyian's philosophy is not only speculative but includes political, psychological, ethical and pedagogical aspects.

The article targets to analyze the main content of Julian Vassian's philosophy in order to find out the effective criteria for the self-determination of the modern Ukrainian nation.

According to the article's target, the authors put the following tasks:

1. To analyze the main traits of Ukrainian national mindset outlined by Julian Vassyian in order to define the "national character" as the main criterion for the identification of the Ukrainian nation.

2. To prove the significance of the triad "idea-volition-aim" in the process of selfdetermination of the Ukrainian nation.

3. To set forth the concept of "national genius" suggested by Julian Vassyian in order to justify its relevance for the modern Ukrainian nation.

The authors of the paper use the following research methods: the comparative method, functional-analytical method and the method of socio-cultural research, hermeneutical method. 
Theoretical, and source basis of the article is formed by the writings of Julian Vassyian as well as the other Ukrainian researchers, who provide an analysis of Ukrainian philosophy and national identity: Dmytro Dontsov [Dontsov, 2000]; Volodymyr Lisovyi [Lisovyi, 2000]; Viacheslav Lypynskyi [Lypinsky, 1995]; George Kasianov [Kasianov, 1999]; Mykola Mikhnovsky [Mikhnovsky, 2000]; Levko Lukyanenko [Lukyanenko, 2006]; Fedir Kyryliuk [ Kyryliuk, 2004]; Anatolii Furman [Furman, 2001]; etc. Authors of the article follow the methodological conclusions on the evaluation of the Ukrainian philosophy and prospects of international relations development presented by Sergii Rudenko in his recent papers "History of Ukrainian Philosophy: Teaching and Evaluation Methodology" [Rudenko, 2018] and "Management Features of International Educational Projects between Universities of Poland and Ukraine." [Rudenko et. al., 2018]

\section{Ukrainian national mindset as the main factor for national identification}

Like all philosophers who studied the nation's questions, Julian Vassyian proposes criteria for the definition of the Ukrainian nation. During the interwar period, Ukrainian territories had no statehood. Therefore, scientists should not only postulate theoretical positions but also formulate some valuable and practical guidelines. Defeat in national liberation campaign made the scholars reconsider the values of the past and propose new effective postulates for national identification.

According to Vassyian, neither the geopolitical situation nor historical adversaries could be claimed as the reasons why Ukrainians were not able to develop a state and identify themselves as a nation. Reflecting on the past, the thinker justifies that the nation's selfidentification issue should be replaced from the political domain and considered from the perspective of spiritual senses.

Whatever the external circumstances, the reason for all the statehood formation failures is the mental peculiarities of Ukrainians. It is the internal spiritual factors that "reveal themselves as the primary factors that assessed the quality of the historical progress" [Vassyian, 2000: 197]. The national character's traits influence appears to be "an organic phenomenon." Whereas external geopolitical factors (territory, power, management principles, etc.) appear to be the consequences of the influence of the national mindset structures of the Ukrainian nation. They make "mostly mechanical" [Vassyian, 2000: 197] impact on the formation and development of the nation as a historical unit.

In his writings "To the main principles of nationalism," "Pacifism and psychology of Ukrainian love-for-peace" and "Back to Shevchenko" Julian Vassyian provides a sharp criticism of the Ukrainian national mindset that had historically formed itself by that time. It's main negatively evaluated traits such as "strong attachment formed to the territory, an inclination to defence rather than expansion, passionless, intellectual laziness" [Vassyian, 2000: 197] make Ukrainians passive and non-creative. All this resulted in the inability to provide the systematic actions that impeded the formation of a strong and politically sustainable state.

All historical cases, when Ukrainians were capable of active actions are claimed to be spontaneous and impromptu rather than regular. All known cases of conscious and organized political action in Ukrainian history were not durable and constructive. Any social event develops according to the following scenario: "improvised explosion, wave raising and then 
long, the deadly dream of spirit" [Vassyian, 1972: 52]. Ukrainians' appearance as a passive defender comes into sharp antagonism with the process of the formation of the Ukrainian state.

Along with the critics of the historically formed peculiarities of Ukrainian national mindset, Julian Vassyian conducts research on their origins. In his opinion, the main peculiarities of Ukrainian national mindset have developed historically. Ukrainians have always been engaged in farming and supported a settled lifestyle. Unlike the nomads, settled nations do not need to develop expansive instincts and aspiration for the struggle. Therefore, the values of the "farmer" do not stipulate moving beyond the particular "comfort zone." Such circumstance contributes to the development of the "defender's" worldview rather than "conqueror." Julian Vassyian argues that the Ukrainians' passivity is a result of a peaceful way of life that prevented the development of active and viable mental traits.

Passivity was manifested not only in the unwillingness to participate in aggressive military actions but in general mental guidance. "Therefore, there is so little entrepreneurship could be found in a typical farmer who is mostly slow, conservative, silent and patient" states Julian Vassyian in his work Pacifism and psychology of Ukrainian love-for-peace [Vassyian, 1958: 16].

In thinker's opinion, ordinary Ukrainians cannot move to a different better way of life because: "the slave's worldview is negative and anything but creative" [Vassyian: 1958: 16]. The sustainable state cannot be formed without systematic purposeful activity.

Along with peacefulness, which causes more harm than good, the philosopher also criticizes another well-known trait of Ukrainian national mindset - sentimentalism. Other common Ukrainian stereotypes such as hospitality and compassion, cannot be considered effective and useful.

Excessive emotionalism of Ukrainians, according to Vassyian, appears to be the result of the mentioned passivity. In contrast, the dynamic activity, representatives of the Ukrainian nation are guided by their feelings and pathetic attitude. The historical retrospective shows, the "sentimentalisation" of almost all historical facts and events. Historical heroes appear to be tragic, the Ukrainian nation hapless and underprivileged and invaders were always shown as negative "fairy-tale heroes."

Julian Vassyian argues that "distinctive tearfulness established itself as a mental peculiarity" [Vassyian, 1958: 2]. This means, that any problem that the Ukrainian nation faces, turns into the emotional despair rather than the motivation to overcome the obstacle.

Such an attitude mostly inclines Ukrainians to refrain from solving problems, which makes the nation formation process ineffective. Excessive emotions facilitate the lack of motivation to struggle against the difficulties. This particular factor, as well as peacefulness, contributes to the formation of a passive worldview. "The weakened will, along with excessive superiority of feeling, manifested itself in us as a passive and conformist type of personality" [Vassyian, 1972: 52]. And this is one of the reasons why the Ukrainian nation has never been able to overcome the passive attitude towards reality and to prove itself as an independent historical unit.

Five years ago, modern theorists of the nation had no doubts about the existence of the Independent Ukrainian State. However, the social and political events in 2014 resulted in the loss of particular Ukrainian territories. Such fact might be considered as a demonstration that by now the Ukrainian nation is not completely formed yet.

Vast majority of modern philosophical, social and political studies focus on the external causes of such situation - informational war, military aggression, economic dependence, 
etc. However, we will try to reconsider this issue developing the philosophical position of Julian Vassyian: "Does the Ukrainian national mindset essentially impacts the formation of a modern Ukrainian nation?"

The modern interpretation of the concept of the Ukrainian nation should be provided from a different perspective. We cannot completely follow the statements of 19th century nation studies. Population migration has led to a policy of territories openness. At the same time, democratisation has put forward the definition of a nation as "being a modern national state" [Meinecke, 2000: 508], which means, that state factor has become more important than ethnic one. However, the problems related to the Ukrainians' values and mental attitudes still remain relevant. Is it possible to overcome the "passive" and "conformist" attitudes?

The problem of mental and value orientations in Ukrainian society remains unresolved. Emphasizing historical and linguistic differences (distinction "West" - "East"), as well as the external influence of foreign states, Ukrainian society still remains unable to consolidate.

Therefore, as a conclusion, the authors suggest returning to the question of reconsideration and transformation the negative traits of Ukrainian national mindset, which hinder the formation of a sustainable state. The relevance of Julian Vassyian's concept is proved by modern studies. Anatolii Furman in his work "Ukrainian national mindset. It's cultural and mental coordinates" claimed the following. "Central and important problem of the Ukrainians' national renaissance is an effective use of national mindset background and typical mental peculiarities of Ukrainians to actualize the process of community and state formation" [Furman, 2001: 10]. The modern nation studies should apply psychological methodology. Only after the defensive, passive and sentimental mindsets are left behind, the Ukrainian nation will be able to stop being indifferent and contribute to the effective organization of the Ukrainian independent, spiritually united states. Such a state would not be just politically united, but spiritually.

\section{"Idea-will-aim" triad as a precondition for the Ukrainian nation's development}

The processes of national formation and national identification cannot be considered in the field of pure theory. Dmytro Dontsov at the beginning of the $20^{\text {th }}$ century developed a concept of the "nationalism of the deed." He claimed that "the basic idea of the healthy nation should be an endeavour to fight." A true nationalism must "strengthen nation will to life, power and expansion" [Dontsov, 2000: 191]. Since the beginning of the $20^{\text {th }}$ century, the issue of an active volitional principle as a condition for human history development was in the focus of the national studies.

Julian Vassyian in his political writings attempts to develop an effective theory of a nation that might be helpful in defining the historical role of Ukraine. In his opinion, a politically mature nation should be based on three key concepts: idea will aim. And the quintessence of these three concepts must be a nation as a unity of active creative individuals.

Vassyian asserts that the concept of the "national idea" appears to be a necessary condition for the organization of the state. According to the philosopher, political understanding of the idea of national unity must be supplemented by the spiritual and value perspectives. "The idea of spiritual unity is the initial natural precondition for all existing and possible forms of unity of Ukrainians" [Vassyian, 1972: 46]. 
In order to become a single community, every representative of the Ukrainian nation must realize his membership in this community. This idea of membership should become part of the real but not a declarative Ukrainian mindset. The idea of unity: "not to be just a loud sound," requires an understanding "whether spiritual unity is only a declarative idea or is being actively followed" [Vassyian, 1958: 46].

The philosophy of the national idea remains one of the most important branches of modern Ukrainian philosophical and political research. Authors suggest focussing on the integral researcher approach to the issue of a Ukrainian national idea expressed by contemporary Ukrainian scholar Volodymyr Sabadukha. "The crux of the Ukrainian national idea is the concept of the national being. This concept is developed from the philosophical reflection on material and spiritual forms of human's and nation's being. This concept regulates the relations between different active subjects" [Sabadukha, 2011: 134]. Such approach postulate that the modern philosophy of the national idea should focus on the research of its spiritual prerequisites.

Julian Vassyian stresses that the national idea is only one of the three key concepts that determine the structure of the nation. The implementation of the national idea is not possible without appropriate voluntary efforts and moral regulations: "into the centre of the single idea that focuses the flows of the divergent desires into a single current, which moves directly to the aim" [Vassyian, 1958: 68].

Along with the realization of the national idea, a common "passive" Ukrainian should be able to rise above his nature, to overcome the "defensiveness" and "indifference" and focus his will on achieving the aim of establishment of an independent Ukrainian spiritually united state. The philosopher emphasizes that — "No will, means no history!" [Vassyian, 1972: 75] and "To unleash the Gordian knot of its historical existence Ukraine may commit heroics for the sake of a new lifestyle" [Vassyian, 1972: 42]. Only fundamental changes in the core of Ukrainian nation will be able to turn it into an active participant in the historical process.

As for the problem of the Ukrainian national mindset, the authors claim that mentioned negative national traits are the manifestation of a weak national will and, therefore, its nonhistorical status. Julian Vassyian writes the following lines in his paper titled "Steppe Sphinx." "Non-dramatic state of Ukrainians' life directly depends on the lack of will. Ukrainians turned their history into the extravaganza, instead of a tragic struggle, which always was, is and will be its true nature" [Vassyian, 1972: 75].

At the same time, when Vassyian was doing his main political and philosophical writings, the Ukrainian nation had an ultimate and certain aim to achieve statehood. The thinker fully shared those intentions, claiming that: "Statehood for a nation is the first condition for the possibility of its growth in any sense" [Vassyian, 1972: 135]. Statehood for the Ukrainian nation appears to be an indispensable condition in order to become the real actor of the historical process because, as Vassyian states, "A nation without a statehood is not able to act independently and to reveal the potential of its peculiarities" [Vassyian, 2000: 207].

Would such aim be still relevant today if Ukrainian independence was achieved in 1991? Julian Vassyian, who did many significant provisions about the future of the Ukrainian nation, would probably give a positive answer to this question. It seems that the first ("mechanical") part of the aim — the political Independence is fulfilled, while the second ("organic") — the spiritual unity of Ukraine, still remains unattainable.

Modern Ukrainian society faces various problems such as the distinction between West and East, conflict of values, different traditions of upbringing, the influence of other political and 
cultural systems, predominance of the matter over the spirit, etc. After gaining independence, Ukraine found itself in a state of "cultural shock" when "western and Soviet value systems collided in the mindset of new Ukrainians" [Galagan \& Shevchenko, 2008: 113-114].

The $21^{\text {st }}$-century globalization processes established values pluralism in Ukrainian society. However, in the late 2000s, the problem of the formation of values became equal to the problem of informational influence. This led to dramatic consequences for Ukraine namely the rise of "anti-Ukrainian sentiment" and the occupation of some territories.

Julian Vassyian's philosophy still remains relevant, because the absence of a clear national idea, which should be implemented by the conscious and active individuals, is the main reason why the spiritual unity of nation does not exist within the existing political state.

Being consistent, philosopher proclaims the priority of "organic" over "mechanical," "internal" over "external," spiritual over political. To stress his ideas he writes the following. "The idea of a spiritual unity... appears to be the spring, which should supply with energy any future political idea of statehood" [Vassyian, 1972: 46].

Modern philosophical and political discourse raises many questions about how to make Ukrainian economics, politics and culture successful. However, modern studies, which touch upon the issues of national self-identity mostly, are focused on its external formation factors (politics, economics, language, history, culture). The concept of self-identity as the unity of idea, will and aim unfortunately still remains underestimated. The authors claim that the globalized society requires much more attention to the real (not artificial) national spiritual unity. The modern nation studies should develop a comprehensive approach to the identification of a nation. It should be focused on value-orientation and practical recommendations on how to increase the motivation of Ukrainians.

\section{National genius as a possessor of Ukrainian spiritual values}

In the previous paragraphs, the authors demonstrated that passive Ukrainian population, which is only capable of "peaceful existence" and "sentimental perception" must change to become the possessor of the national idea of unity. The development of new values and life benchmarks will form the new Ukrainian nation as an active subject of the historical process.

However, the issue on how to make Ukrainians give up their passiveness for the activeness still remains problematic. Are there certain mechanisms through which "quantity" can turn into "quality"?

To develop this issue, Julian Vassyian introduces the concept of "national genius." It is a commonly held opinion that geniuses are individuals who "do not require any preparatory stages for their creative impulses" [Arnaudov, 1970: 25]. Genial people are those who are not susceptible to the common mental and value orientations. Ukrainian national geniuses are those individuals who are able to overcome "passivity" and "defensiveness" and to inspire common Ukrainians with their ideas and actions.

According to Vassyian Taras Shevchenko is the most influential personality for the Ukrainian nation. He believes that poets' creativity was "A brilliant improvisation of that enigmatic land" [Vassyian, 1958: 47].

The poet's creative work has become an impetus for the development of brand new, unique Ukrainian values. Poet's example was followed by numerous scientists, artists, and social and cultural figures. "His poetry gave access to the spiritual motherland engaging passive Ukrainians to be more active" [Vassyian, 1958: 50]. 
Aman who outdistanced his time has created the new Ukrainian reality, acting as "Immediate, intensive nationality, which sounds like internal elements of the spiritual movement..." [Vassyian, 1958: 55]. Taras Shevchenko has created a strong worldview foundation, which became the starting point for Ukrainian nationalist ideas.

However, after some time the true historical value of Taras Shevchenko as "national genius", and spiritual leader of the Ukrainian nation has been replaced by the role of sentimental Poet. Sentimentalism of the Ukrainian nation has led to the fact that "the artificial democratic sincerity, an obsessive tearful love to unsuccessful Kobzar - spoiled the true image of the poet by demonstrative admiration" [Vassyian, 1958: 45].

Shevchenko's essential value for the national mindset was lost. The versatility of the poet's creative heritage made possible to use it by various ideological systems. In different times, he was hailed as "enemy of tsarists," "defender of underprivileged," "lyric poet," etc. On this issue, Vassyian writes the following "After all transformations to poet's historical image, done by different political and social ideologies Shevchenko has lost his impulsive individual charm" [Vassyian, 1958: 45].

Along with Taras Shevchenko Julian Vassyian also mentioned other geniuses who made an essential impact on the development of the Ukrainian nation. For instance, he provides historical and philosophical scrutiny on Bohdan Khmelnytsky. Vassyian believes that "The greatness of Bohdan's spirit and work outperforms all our achievements in our history" [Vassyian, 1972: 54].

However, the authors have already mentioned that Vassyian's philosophical works of Julian were not only theoretical but also included a practical component. For this reason, Vassyian's concept of "national genius" would be incomplete without an analysis of his contemporary "national geniuses" Symon Petliura and Yevhen Konovalets. His Chicago oral report titled "To the anniversary..." was devoted to the analysis of those two personalities' contribution to the development of Ukrainian nationalism as an effective political and philosophical worldview. For the Ukrainian nation, he stresses, "Symon Petliura and Yevhen Konovalets two valuable tablets, even more, valuable book as well as the most valuable monument" [Vassyian, 1972: 143].

Julian Vassyian hails these two personalities much more than just nameless "fighters for the Ukrainian's freedom." They not only participated directly in the organization of the Ukrainian state in 1917-1922. However, became the real spiritual leaders who were able to consolidate the nation and direct its efforts to dynamic and effective actions. Vassyian emphasises their essential impact on the development of Ukrainian national idea: "This two personalities stood out from the crowd of artists, builders and bricklayers, scaled the heights of the historical structure and became visible because of the light of their ideas" [Vassyian, 1972: 145].

Practical influence of mentioned leaders is, in Vassyian's opinion, undoubted as well. He claims that at the beginning of the Ukrainian National Revolution, thanks to the contribution of Petliura and Konovalets a lot of courage, conscious and inspired warriors joined the Ukrainian army [Vassyian, 1972: 146]. Because of national significance, they both were violently murdered by the external enemies of the Ukrainian nation.

One of the most important problems of the modern Ukrainian nation is a lack of respectable leaders. Western governing experience shows that political leadership is responsible for the successful formation of national values and ideology. In modern globalised society, the "might is right" principle is since long time ago recognised as anti-human and dangerous. Therefore, the efficient governance and consolidation of the population move to the foreground. Such a 
claim is reflected in various modern Ukrainian studies. Ukrainian scholar O. Telpis asserts the

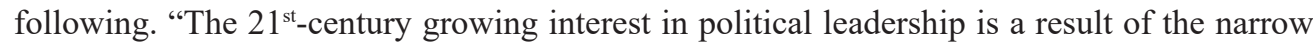
power problem-solving frames as well as the acceptance of the values and principles of the informational society, ideological and political pluralism" [Telpis, 2012: 173].

Unfortunately, most political leaders put their own motivational guidelines to the foreground and are not able to unite the nation for the new stage of development. Because, "Under the democratic conditions of free competition and power transparency, the power is likely to be possessed by those who more than others strive for it" [Derzhanovska, 2014: 313]. Therefore, in authors' opinion, the problem of the leader as "national genius" who will be able to unite the Ukrainian nation by activating the power of Ukrainian will in order to overcome the political, economic and social crisis still remains relevant.

Therefore, the requirements of a modern political leader should be very high. Some modern political scientists propose new effective criteria for political leadership, which are sensible. The scholars suggest that, along with the party platform, some mental and value attitudes of candidates should be assessed: "the motives for doing politics... the targets, ideals, emotions and moods, knowledge, information, thoughts, which are owned and distributed" [Kyryliuk, 2004: 18].

Because of pluralistic values and a globalising society, the Ukrainian nation requires an extraordinary leader who will be able to change the national mindset for the sake of national consolidation. In the authors' opinion, the concept of the "national genius" by Julian Vassyian is able to become an effective instrument for developing the future "political leader" image.

\section{Conclusions}

Under the conditions of globalisation, "blurring" of borders and migration, Ukraine faces the necessity for preserving the nation. To contribute to the establishment of a sustainable state, Ukrainian scientists and public activists should replace the conservative interpretations of the Ukrainian nation with the new, based on a complex synthetic approach.

Despite the time distance, the ideas of Julian Vassyian still remain relevant today and should be reconsidered in order to form the future Ukrainian nation image. Thinkers should leave the commonly accepted approaches for self-determination of the Ukrainian nation behind.

Such criteria as language, territory, economic factors, common historical heritage and past seem to be ineffective for self-identification of the modern Ukrainian nation. Self-identification appears to be essential for being a part of the nation. From being mentally defensive, the average person everyone should move to the active participation in history and formation of the nation.

A nation must be formed by the spiritual leaders, by its most educated, initiative, volitional and patriotic representatives. "National geniuses" must not only meet contemporary social requirements but also be able to outstrip their time by creative solutions.

The methods suggested by Julian Vassyian at the beginning of the $20^{\text {th }}$ century still remain relevant. As well as Immanuel Kant's ideas on the "social contract" and "perpetual peace" were recognised only 150 years after they were suggested, Julian Vassyian's conception of the Ukrainian nation as a spiritual self-identification can be effectively applied only to modern non-conservative, globalised society. 
The Ways and Means of the Ukrainian Nation's Self-Determination: a Philosophical Look into the Future by Julian Vassyian by Daria Pohribna and Vadym Tytarenko

\section{References}

Ageev, Alexander, and Eugene Loginov. Nooeconomy: a certain economy in an uncertain future. Journal of the ES. 2011. http://spkurdyumov.ru/economy/nooekonomika (in Russian).

Arnaudov, Mikhail. Psychology of Creativity in Literature. Moscow: Progress, 1970.

Bachinsky, Julian. Economic Bases for the Independence of Nations. Nationalism. Anthology.

[Protsenko O., Lysovy V., Bilyk etc.] Kyiv: Smoloskyp, 2000: 133-147.

Cultural Studies. Student's Book. Kyiv: SETUT, 2008.

Derzhanovska, Svitlana. The Essence of Political Leadership in Researches of Modern Ukrainian Scientists. Efficacy Public Administration. Issue 40, 2014: 310-316.

Dontsov, Dmytro. The ideology of the nationalism of the deed. Nationalism. Anthology. Kyiv: Smoloskyp, 2000: 188-196.

Furman, Anatolii. Ukrainian National Mindset and Its Cultural and Psychological Coordinates. Psychology of culture. Vol.1, 2001: 9-73.

Kasianov Heorhii. Theories of Nation and Nationalism. Kyiv: Lybid, 1999.

Kyryliuk, Fedir. Political Science. Student's Book. Kyiv: Health, 2004.

Lypynsky, Vyacheslav. Letters to brothers-farmers on the idea and organisation of the Ukrainian monarchy. Philadelphia, 1995.

Lisovyi, Vasyl. What is a national (Ukrainian) idea? Nationalism. Anthology. Kyiv: Smoloskyp, 2000: 593-626.

Lukyanenko, Levko. The national idea and national will. Kyiv, 2006.

Meineke, Friedrich. A general view of the nation, national state and cosmopolitanism. Nationalism. Anthology. Kyiv: Smoloskyp, 2000: 503-514.

Mikhnovsky, Mykola. Independent Ukraine. Nationalism. Anthology. Kyiv: Smoloskyp, 2000: 147-158.

Rudenko, Sergii, Roman Sapeńko, Oleg Bazaluk, and Vadym Tytarenko. Management Features of International Educational Projects between Universities of Poland and Ukraine. Naukovyi Visnyk Natsionalnoho Hirnychoho Universytetu. 2, 2018: 142-147. https://doi. org/10.29202/nvngu/2018-2/21.

Rudenko, Sergii. History of Ukrainian Philosophy: Teaching and Evaluation Methodology. Future Human Image, Vol. 10, 2018: 85-91. https://doi.org/10.29202/fhi/10/9

Potebnja, Alexander. Thought and Language. Kharkiv: 1913.

Sabadukha, Volodymyr. Ukrainian National Idea and Concept of Personal Being. IvanoFrankivsk: Folio, 2011.

Teplyis, O. Political Leadership in the $21^{\text {st }}$ Century: Updating of Individual Information Strategies in International Relations. Actual Problems of International Relations. Vol. 107 (part 2), 2012: 162-173.

Vassyian, Julian. Ukraine in War. Selected Works. Vol. 1: Steppe Sphynx. Social and Philosophical Essays. Toronto: Yevshan-zillia, 1972: 173-207.

Vassyian, Julian. To the Anniversary..., Selected Works. Vol. 1: Steppe Sphynx. Social and Philosophical Essays. Toronto: Yevshan-zillia, 1972: 136-160.

Vassyian, Julian. To the Main Principles of Nationalism. Nationalism. Anthology. Kyiv: Smoloskyp, 2000: 197-208.

Vassyian, Julian. Ideological Foundations of Ukrainian Nationalism. Selected Works. Vol. 1: Steppe Sphynx. Social and Philosophical Essays. Toronto: Yevshan-zillia, 1972: 119135. 
Vassyian, Julian. Over Rubicon. Selected Works. Vol. 1: Steppe Sphynx. Social and Philosophical Essays. Toronto: Yevshan-zillia, 1972: 39-47.

Vassyian, Julian. Back to Shevchenko. Social and Philosophical Essays. Chicago: Independent Ukraine, 1958: 40-58.

Vassyian, Julian. Pacifism and Psychology of Ukrainian Love-to-peace. Social and Philosophical Essays. Chicago: Independent Ukraine, 1958: 5-30.

Vassyian, Julian. Steppe sphynx. Selected Works. Vol. 1: Steppe Sphynx. Social and Philosophical Essays. Toronto: Yevshan-zillia, 1972: 49-80. 